\title{
Innovative Methods in Management and Raising the Quality of Higher Professional Education in Russia
}

\section{Métodos innovadores en la gestión y la mejora de la calidad de la educación profesional superior en Rusia}

\author{
Maria A. Erofeeva \\ Moscow University of the Ministry of Internal Affairs of Russia Named After V.Y. Kikot, \\ Moscow, Russia \\ ORCID: http://orcid.org/0000-0001-7176-513X
}

\section{Alla N. Stolyarova}

State University of Humanities and Social Studies, Kolomna, Russia

ORCID: https://orcid.org/0000-0003-0722-5141

\begin{abstract}
Aleksandra I. Terekhova
Head of the Department of Management and Social Work at RSSU (Minsk branch), Minsk, Belarus

ORCID: http://orcid.org/0000-0003-1957-5683
\end{abstract}

Alla V. Ignatyeva

Moscow City University, Moscow, Russia

ORCID: https://orcid.org/0000-0002-1799-7869

Nelya A. Deberdeeva

Plekhanov Russian University of Economics (Moscow University), Moscow, Russia

ORCID: https://orcid.org/0000-0003-2357-2450

\section{Anna K. Zebnitskaya}

Vladimir State University named after Alexander and Nikolay Stoletovs, Vladimir, Russia ORCID: https://orcid.org/0000-0002-4556-6580

\section{Mikhail G. Leontev}

Psychological and Legal Communications, Moscow State University of Civil Engineering (National Research University), Moscow, Russia

ORCID: http://orcid.org/0000-0001-8192-6523

Received 02-12-20 Revised 02-25-20 Accepted 06-13-20 On line 06-29-20

*Correspondence

Email: Erofeeva-ma72@yandex.ru
Cite as:
Erofeeva, M.A., Stolyarova, A.N., Terekhova, A.I., Ignatyeva,
A.V., Deberdeeva, N.A., Zebnitskaya, A.K., Leontev, M.G.
(2020). Innovative Methods in Management and Raising the
Quality of Higher Professional Education in Russia. Propósitos
$y \quad$ Representaciones, 8 (SPE2), e653. Doi:
http://dx.doi.org/10.20511/pyr2020.v8nSPE2.6523 


\section{Summary}

Economic and political changes in contemporary society lead to reforms of many social spheres. The system of education in general and higher professional education in particular is no exception. The issue of ensuring the quality of education has recently attracted great attention in all countries of the world. The key problem of reforming education is raising its quality. In this paper, the object of research was the quality of education provided by higher education institutions. The authors have conducted the analysis of models for raising the quality of education and qualimetry of the laboratory work quality based on a survey of teachers and students. The QFD method was described by the example of its application in five universities of the Russian Federation. It has been proved that this method can provide the university with a planning tool with which higher education institutions can provide services that fully meet the requirements of customers (students, parents, employers, the state and society as a whole), thereby ensuring the suitability of the system to meet external requirements - the Fitness-for-Purpose approach (building goals based on the external environment). In addition, it has also been substantiated that the application of this method in the system of higher professional education will ensure the suitability of the system to achieve its own goals - the Fitness-for-Purpose approach (development, improvement, effective management). Thus, the QFD method will make it possible to support of all types of coordinated activities for the leadership and management of higher education institutions in relation to quality, as well as a set of developed regulatory and methodological documents that determine the content, technologies, methods and means of work of all officials, teachers and students to further improve the quality of educational process, thereby ensuring the competitiveness of higher education institutions and effective development on the global market of educational services

Keywords: Innovative Method; System of Education; Quality of Education: Competitiveness of Higher Education Institutions; Management of Education.

\section{Resumen}

Los cambios económicos y políticos en la sociedad contemporánea conducen a reformas de muchas esferas sociales. El sistema de educación en general y la educación profesional superior en particular no es una excepción. La cuestión de garantizar la calidad de la educación ha atraído recientemente una gran atención en todos los países del mundo. El problema clave de reformar la educación es aumentar su calidad. En este artículo, el objeto de investigación fue la calidad de la educación proporcionada por las instituciones de educación superior. Los autores han llevado a cabo el análisis de modelos para elevar la calidad de la educación y la calidad del trabajo de laboratorio basado en una encuesta de docentes y estudiantes. El método QFD fue descrito por el ejemplo de su aplicación en cinco universidades de la Federación Rusa. Se ha demostrado que este método puede proporcionar a la universidad una herramienta de planificación con la que las instituciones de educación superior pueden proporcionar servicios que cumplan plenamente los requisitos de los clientes (estudiantes, padres, empleadores, el estado y la sociedad en general), lo que garantiza la idoneidad del sistema para cumplir con los requisitos externos: el enfoque de aptitud para el propósito (objetivos de construcción basados en el entorno externo). Además, también se ha comprobado que la aplicación de este método en el sistema de educación profesional superior garantizará la idoneidad del sistema para lograr sus propios objetivos: el enfoque de aptitud para el propósito (desarrollo, mejora, gestión eficaz). Por lo tanto, el método QFD permitirá apoyar todo tipo de actividades coordinadas para el liderazgo y la gestión de las instituciones de educación superior en relación con la calidad, así como un conjunto de documentos normativos y metodológicos desarrollados que determinan el contenido, las tecnologías y los métodos. y los medios de trabajo de todos los funcionarios, docentes y estudiantes para mejorar aún más la calidad del proceso educativo, asegurando así la competitividad de las instituciones de educación superior y el desarrollo efectivo en el mercado global de servicios educativos. 
Palabras clave: Método innovador; Sistema educativo; Calidad de la Educación; Competitividad de las Instituciones de Educación Superior; Gestión de la Educación.

\section{Introduction}

At present, in the context of the global modernization of contemporary society, the matter of the quality of the system of higher professional education is very important. Today, the quality of education is one of the most important criteria for the competitiveness of higher education institutions. It is the quality of the educational process that determines the effectiveness and success of activities provided by a higher education institution.

The need to raise the quality of the system of higher professional education in Russia, namely the methodology and technology to provide training for students at higher education institutions, the quality level and the innovativeness and universality of the knowledge provided is becoming more and more obvious. The relationship between the level of quality of educational processes at higher education institutions and the level of effectiveness of managing these processes determines the direct dependence of the education quality enhancement and the improvement of legal and economic mechanisms to regulate this activity at all levels of its organization.

The course on modernization and innovation of the economic and political systems in our country also affects the system of higher professional education, the goal of which is to train highly qualified personnel for work in various sectors of the Russian economy and social sphere.

Contemporary society is now largely a society of knowledge. Knowledge is a necessary and extremely important resource for the successful life of any individual. In this regard, the issue of raising the quality of higher professional education affects all participants in the educational process. For instance, higher education institutions need a high level of quality education to ensure its competitiveness in the global market of educational services. For the teaching staff of higher education institutions, the quality of education received by students determines the level of training and qualifications of the teachers themselves, and again, competitiveness in the modern economy of educational services. For students, a high level of quality of education received by them is necessary for their effective self-realization in society, for the organization of their professional activities and building a promising path of their professional development. The labor market, which forms the demand for highly qualified specialists, also depends on the real quality level of the system of higher professional education (Gludkin, Gorbunov \& Zorin, 2011; Kroeger \& Tewson, 2011; Pryadko \& Ishkov, 2016).

It should be pointed out that in recent decades, attempts have been made, at the state level, to raise the quality of the system of higher professional education to a higher level by transforming traditional organizational forms of educational activity; its content and conceptual component; modernization of educational standards, programs and curricula; the use of modern information and telecommunication technologies; changes in mechanisms of financing and much more. However, to date, the level of development of the quality of the system of higher professional education in Russia in the system of world rankings remains very low (Kuzmin, 2012; Bonkalo, Erofeeva \& Gorokhova, 2008; Ishkov, 2014; Leontev, 2016).

It should also be noted that recently the question of bringing science and practice together has been raised more often as the most important prerequisite for improving the quality of the system of higher professional education. For example, in the context of modern technological challenges, the key objective of the Government of the Russian Federation, indicated in the Decree of the President of the Russian Federation (2018) of May 7, 2018 No. 204 "On National Goals and Strategic Tasks of the Development of the Russian Federation for the Period till 2024" is to accelerate technological development of the country, to increase the number of organizations 
involved in technological innovation. The significance of the development of high-tech areas is due to the possibility of obtaining results and the formation of competences required for the transition to the implementation of new priorities of the scientific and technological development of the Russian Federation, which meet great challenges (Miloradova \& Ishkov, 2019a; Goloshumova et al., 2019b).

One of the causes of a low ranking of the Russian system of education in the world rankings of higher education institutions may be, in our opinion, the insufficient development of a scientific understanding of the quality management processes of higher education. In addition, the transition to a three-tier system of education in Russia, improving the bases of functioning the system of education, establishing methods and criteria to assess the quality of higher professional education cannot be successfully, effectively solved without doing scientific research in the field of education quality management (Samodurova, 2011). The results of such studies can serve as the basis for the development of a scientifically and methodologically sound mechanism for reforming the Russian system of education; setting and achieving goals that meet modern public policy objectives; solving problems and implementing measures aimed at developing the system of Russian education both in Russia and in the world community (Miloradova \& Ishkov, 2019b).

The problem of continuous improvement of educational services is especially important today, since contemporary education strives to satisfy the needs of a dynamically developing society. An important task is to ensure not only a high level of professional training of students, but also the nature and methods of social development in the professional sphere, successful adaptation and self-realization. Also, the Bologna process and Russia's participation in it is one important aspect of the importance of the quality problem of higher professional education. In the framework of the Bologna process, it is proposed as a recommendation to shift to practically oriented education - to train a graduate with practical readiness to perform professional tasks. The adequacy of the acquired basic, general professional and applied knowledge and skills is the basis of suitability for employment (Leontev et al., 2018; Goloshumova et al., 2019a).

Studies conducted by personnel recruitment agencies (Super Job, HH, etc.) indicate that in the whole country only $50 \%$ of graduates from Russian universities are employed according to their specialties. The reason for this is the mismatch of the level of development of professional, socio-psychological and competitive potential of graduates with the criteria of modern competition. Poor preparedness of young specialists for self-development and self-realization in the new conditions reduces the level of competitiveness of university graduates on the labor market. The most important problem of Russian professional education is the problem of the quality of educational activity in the system of higher professional education (Ishkov \& Magera, 2015; Leontev, 2017; Mitin et.al., 2018).

In all countries of the world, great attention has been focused on the issue of ensuring the quality of education. Numerous works by both domestic and international researchers in the field of pedagogy, psychology, economics, law and legal studies have been devoted to the issues of improving the quality of the system of education. Taking account of the topicality and significance of the stated problem, the goal of our work is to identify opportunities to improve the quality of education giving examples of higher education institutions in the Russian Federation. To achieve the goal set in the work, we tackled the following tasks: qualimetry of the quality of laboratory work of universities; description of the QFD method in a higher education institution as an example. The object of the work is the quality of education of Moscow University of the Ministry of Internal Affairs of Russia Named After V.Y. Kikoty, State University of Humanities and Social Studies, Moscow City University, Plekhanov Russian University of Economics and Moscow State University of Civil Engineering. The subject of the study is the management of the quality of education using the Pareto diagram, qualimetry, the QFD method, as well as the identification of problems that arise at the stages of training and ways of solving them.

\section{Materials and Methods}


The goal of the study is to assess the quality of laboratory work by teachers and students of Moscow University of the Ministry of Internal Affairs of Russia Named After V.Y. Kiko, State University of Humanities and Social Studies, Moscow City University, Plekhanov Russian University of Economics and Moscow State University of Civil Engineering. The objectives of the study are the assessment and importance of the study criteria.

University of the Ministry of Internal Affairs of Russia Named After V.Y. Kiko, State University of Humanities and Social Studies, Moscow City University, Plekhanov Russian University of Economics and Moscow State University of Civil Engineering. In total 600 people were interviewed. Among the students, 50\% of girls and 50\% of boys in the age group from 17 to 21 years were interviewed.

The assessment was made on a five-point scale about the importance and evaluation of the subdivisions of the university where laboratory classes were conducted.

The procedure for assessing the quality of laboratory classes was carried out in two stages. The first stage comprised the determination of criteria for assessing laboratory classes. After selecting the list of criteria, a search was made for the normalized coefficients of importance of each of the criteria. The importance of determining normalized coefficients was carried out using the method of normalizing average expert estimates. Each of the selected experts was asked to evaluate the importance of a particular criterion in accordance with scores (from 0 to 10 points).

The unnormalized factors of importance $\mathrm{Ki}$ of each i criterion is determined by averaging the opinions of experts and is calculated by the formula (1):

$$
\mathbf{K}_{i}=\frac{1}{N} \sum_{j=1}^{N} b_{j i}
$$
2015).

where bji - integer evaluation of the criterion under number i given by the $\mathrm{j}$-expert (Kostin,

According to a teachers' and students survey as a result of calculations according to formula (1), the following non-normalized factors of importance were obtained (Table 1).

Table 1.

Unnormalized factors of importance

\begin{tabular}{lcccccccccc}
\hline $\begin{array}{l}\text { Factors of } \\
\text { importance }\end{array}$ & $\mathrm{F}_{1}$ & $\mathrm{~F}_{1}$ & $\mathrm{~F}_{1}$ & $\mathrm{~F}_{1}$ & $\mathrm{~F}_{1}$ & $\mathrm{~F}_{1}$ & $\mathrm{~F}_{1}$ & $\mathrm{~F}_{1}$ & $\mathrm{~F}_{1}$ & $\mathrm{~F}_{1}$ \\
\hline Teachers & 7,6 & 7,3 & 7,6 & 8 & 10 & 7,3 & 7,6 & 6,3 & 5,3 & 8 \\
Students & 8,5 & 6,7 & 9,2 & 7,8 & 9,3 & 8,2 & 7,9 & 8,3 & 9,3 & 8,2 \\
\hline
\end{tabular}

After this the factors of importance are normalized, as a rule, by one: 


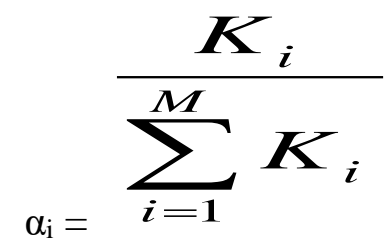

From formula 2 we get such factors of importance - by teachers and students (table 2).

\section{Table 2.}

Normalized factors of importance

\begin{tabular}{lcccccccccc}
\hline $\begin{array}{l}\text { Factors of } \\
\text { importance }\end{array}$ & $\alpha 1$ & $\alpha 2$ & $\alpha 3$ & $\alpha 4$ & $\alpha 5$ & $\alpha 6$ & $\alpha 7$ & $\alpha 8$ & $\alpha 9$ & $\alpha 10$ \\
\hline Teachers & 0,12 & 0,12 & 0,13 & 0,12 & 0,13 & 0,12 & 0,15 & 0,12 & 0,1 & 0,13 \\
Students & 0,11 & 0,1 & 0,12 & 0,1 & 0,12 & 0,1 & 0,09 & 0,12 & 0,1 & 0,12 \\
\hline
\end{tabular}

The second stage included the assessment of scientific, technical and social indicators of educational activity. This procedure was also performed by experts: 10 teachers and 10 students. The expert assessment for each selected criterion was carried out by experts independently by filling out sample survey tables. After the experts ranked the criteria, the estimates for each selected criterion were summarized.

In our study, the average expert score for each criterion is multiplied by the normalized factor of importance, and then they are summarized in all criteria which ultimately gives the criterion ranking. The ranking is found by processing the survey table according to the formula (3):

$$
\sum_{\mathrm{R} \text { project }}^{M}\left(\frac{\alpha_{i}}{N} \sum_{j=1}^{N} R_{j i}\right)
$$
expert.

where $R_{j i}$ - the project assessment in the criterion under the number $i$, given by the $j$ -

After calculating by teachers, according to formula (3), we obtain such rankings according to the above criteria (table 3 ).

Table 3.

Rankings in all criterio

\begin{tabular}{llccccccccc}
\hline $\begin{array}{l}\text { Factors of } \\
\text { importance }\end{array}$ & $\mathrm{R}_{1}$ & $\mathrm{R}_{2}$ & $\mathrm{R}_{3}$ & $\mathrm{R}_{4}$ & $\mathrm{R}_{5}$ & $\mathrm{R}_{6}$ & $\mathrm{R}_{7}$ & $\mathrm{R}_{8}$ & $\mathrm{R}_{9}$ & $\mathrm{R}_{10}$ \\
\hline Teachers & 0,15 & 0,12 & 0,12 & 0,12 & 0,12 & 0,12 & 0,15 & 0,12 & 0,1 & 0,12 \\
Students & 0,1 & 0,07 & 0,05 & 0,15 & 0,1 & 0,15 & 0,13 & 0,07 & 0,13 & 0,04 \\
\hline
\end{tabular}


After counting by students, according to formula (3), we obtain such rankings according to the abovementioned criteria (table 3).

At the next stage of our study, we used the QFD method. The goal of QFD is to provide a higher education institution with a planning tool with which the higher education institution can offer its services in accordance with customers' requirements (clients).

Since the product development is determined by quality, costs and its multifunctional character, it is the customer's wishes that should systematically influence the development area precisely. But in neighboring subdivisions, such as: production preparation, production, assembly, shipment and after-sales service, the customer's "voice" must be translated into the "language" of these departments so that all activities can be reduced to fulfilling the customer's wishes (Popov, Surkova \& Babkin, 2013; Bragin \& Korolkov, 2013).

Specifying the customer's requirements. One should conduct a survey of consumers to identify their requirements for a new service. Highlighting priority consumer requirements. It is expedient to choose the most important and most frequent consumer requests.

The translation of consumers' requirements into general characteristics (quality indicators). The objective of this stage is to find the answer to the question "How to do it?", that is, what product quality indicators should ensure the satisfaction of consumer requirements (Efimov, 2007).

Thus, we have identified the tightness of the relationship between the degree of satisfaction of requirements and the value of the product characteristics (table 4). With a high tightness of the relationship, we take the correlation coefficient (in absolute value) equal to 1 , and if the correlation is not very large, then $1 / 2$, and in the absence of correlation - 0 . We estimate the direction of the regression line by the signs plus and minus.

Table 4.

Correlation between consumer requirements and education characteristics

\begin{tabular}{|c|c|c|c|c|c|c|c|}
\hline \multirow[b]{2}{*}{$\begin{array}{l}\text { Consumer's } \\
\text { requirements } \\
\text { (CR) }\end{array}$} & \multirow[b]{2}{*}{$\begin{array}{l}\text { Rankin } \\
\text { g (Rcr) }\end{array}$} & \multicolumn{6}{|c|}{ Education characteristics } \\
\hline & & $\begin{array}{l}\text { Program } \\
\text { s in } \\
\text { conformi } \\
\text { ty with } \\
\text { standards } \\
\left(\mathrm{EC}_{1}\right)\end{array}$ & $\begin{array}{l}\text { Educati } \\
\text { onal } \\
\text { technol } \\
\text { ogies } \\
\left(\mathrm{EC}_{2}\right)\end{array}$ & $\begin{array}{l}\text { Scope of } \\
\text { knowledg } \\
\text { e }\left(E C_{3}\right)\end{array}$ & $\begin{array}{l}\text { Degree } \\
\text { of } \\
\text { novelt } \\
y \\
\left(\mathrm{EC}_{4}\right)\end{array}$ & $\begin{array}{l}\text { Level of } \\
\text { the } \\
\text { quality of } \\
\text { graduates } \\
\text { 'training } \\
\left(\mathrm{EC}_{5}\right)\end{array}$ & $\begin{array}{l}\text { Duratio } \\
\mathrm{n} \text { of } \\
\text { study } \\
\left(\mathrm{EC}_{6}\right)\end{array}$ \\
\hline Demand & $+0,2$ & $+0,5$ & $+1,0$ & $+1,0$ & $+1,0$ & $+1,0$ & $+0,5$ \\
\hline $\begin{array}{l}\text { Level of } \\
\text { professional } \\
\text { training }\end{array}$ & $+0,5$ & $+1,0$ & $+1,0$ & $+1,0$ & $+1,0$ & $+1,0$ & $+1,0$ \\
\hline Comfort & $+0,05$ & 0 & 0 & $+0,5$ & 0 & 0 & $+0,5$ \\
\hline Working capacity & $+0,5$ & $+0,5$ & +1 & $+1,0$ & $+1,0$ & $+1,0$ & $+0,5$ \\
\hline $\begin{array}{l}\text { Duration of } \\
\text { education }\end{array}$ & $+0,2$ & $+1,0$ & $+0,5$ & 0 & $+0,5$ & $+0,5$ & $+1,0$ \\
\hline Cost of education & +1 & 0 & 0 & $+0,5$ & $+0,2$ & 0 & $+1,0$ \\
\hline
\end{tabular}


Comparing consumer and technical characteristics with each other, it is possible to detect cases of both independence and positive correlation.

After filling out the table, we calculate the weighted mean value of the correlation coefficient of each $(j)$ education characteristic according to the formula:

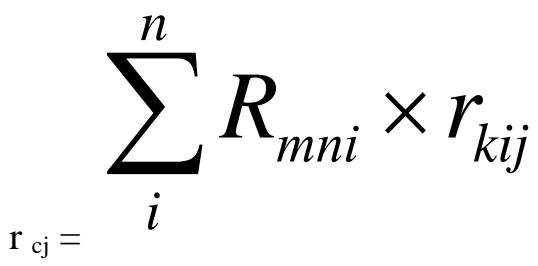

where $r_{c j}$ is the weighted mean value of the correlation coefficient of the $j$ education characteristic (EC); $\mathrm{R}_{\mathrm{mni}}$ - the ranking of the $\mathrm{i}$ customer requirement; $\mathrm{r}_{\mathrm{kij}}$ is the value of the correlation coefficient between $\mathrm{ECj}$ and $\mathrm{CRj} ; \mathrm{n}$ is the number of the customer's requirements.

Based on the obtained weighted mean values of the correlation coefficients for each education characteristic, we plot the dependence diagram (Fig. 1).

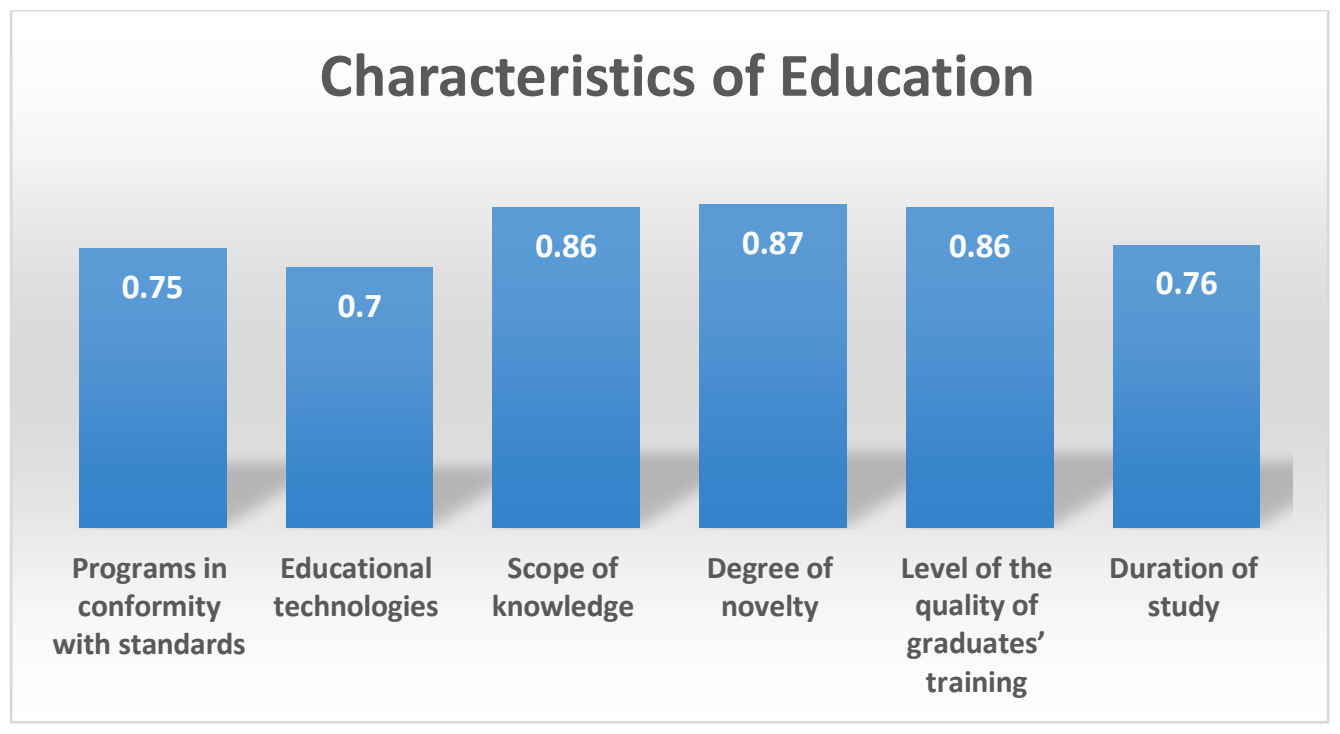

Figure 1. The diagram of the dependence of average values of correlation coefficients for each characteristic of education.

Thus, the QFD method makes it possible to identify significant characteristics of education for the consumer. It gives a possibility to pay attention to the weak ones and take measures to increase and improve them.

\section{Results and Discussion}

The prospective student encounters certain problems already at the stage of choosing a higher educational institution. The reason for this is: an insufficient amount of information that the higher 
education institution provides about its activities. For instance, the higher education institution should hold open days, meetings with school leavers and prospective applicants. It is also possible to use various types of advertising.

Even if the future student knows about the higher education institution as such, there are often problems with choosing a course or a program. Faculties do not always provide the required information about what specialists they train.

So, the applicant chose a higher education institution and a course. Now he faces the problem of submitting documents. The university needs to create the appropriate conditions for the admission committee where the applicant could receive all the necessary information without any lines of people would create an atmosphere of a holiday. It is necessary to provide separate rooms for staff members of the admission committee. It is also important to select competent personnel, as well as to develop an intuitive and effective methodology for submitting documents.

The applicant submitted documents, passed the entrance exams. Now he faces the problem of gaining admission for the chosen program. Many applicants simply do not know whether they were accepted as students or not. For example, the twentieth applicant in line for fifteen budget seats. If he submits the original documents for this program, there is a possibility that he will not go anywhere. However, if he submits the original documents for another course, which he is sure to be enrolled in, five people in line in front of him may also not submit the original documents and in this confusion the applicant will not enter the program of his dreams. This system of student enrollment should be reformed, which the Ministry of Science and Higher Education of the Russian Federation is trying to do.

Let us move to the problems that the student faces directly in the learning process. It should be noted here that in our age of informatization and modernization, universities use Internet resources very little. On the official websites of the university, one can find only general information related mainly to applicants and teachers. For example, on the website one can publish the class schedule, the work schedule of the departments and teachers in them. Now almost all students have access to the Internet, and this innovation will facilitate their learning process. One can also publish all the changes in the schedule, both classes and exams, which will allow students to save a lot of time on a trip for a transferred class.

We will touch upon other problems of a student in his learning:

- how to get to the place of study. Many students live in areas located far from the university, including rural districts;

- the availability of qualified teaching staff;

- the availability of understandable and useful guidelines for subjects;

- the availability of educational literature on the subject;

- the availability of equipped facilities for training;

- the availability of equipment necessary both for study and for scientific work;

- the possibility to engage in scientific activities;

- the possibility to engage in physical education and develop in sports;

- the availability of qualified personnel in dean's offices and departments that can help in solving certain problems;

- the possibility to get a consultation from a teacher.

These problems can be solved using economic and methodological methods. For example, it is possible to arrange bus service that will bring students to a place of study and take them home; it is possible to rent new rooms or repair old ones. One can purchase additional equipment for laboratories and hire technical staff. 
Some issues are resolved without any costs. So, you can make teachers publish guidelines on their subject. It is possible to issue an order that each teacher should have certain appointment hours for students on all issues of their interest. The university should encourage students to participate in scientific activity not only with material rewards, the student should be aware that his work is valuable and useful.

\section{Conclusion}

The constant changes of social, economic and political conditions of the contemporary world lead to a change in social consciousness. We can achieve this by improving and simplifying our activity as a whole.

The object of work was the quality of education provided by institutions of higher education. Thus, an analysis of the models for improving the quality of education was carried out. Since control over laboratory classes will allow us to solve one of the main shortcomings of the university's internal audit, we evaluated the quality of laboratory work based on a survey of teachers and students of Ulyanovsk State University. A survey of university students and teachers included 600 respondents, while among students $50 \%$ of girls and $50 \%$ of boys in the age group from 17 to 21 were interviewed.

To conduct the survey, a list of criteria for assessing laboratory work was selected and normalized importance factors for each of the criteria were determined. As a result of mathematical processing of the survey data, the stars of the quality of laboratory work were built at the Department of Engineering Physics of the Faculty of Engineering and Physics of High Technologies and an experimental assessment of the scientific, technical and social indicators of the educational process was obtained. In addition, the QFD method was described using the example of a university. This method can provide the university with a planning tool with which it can offer its services that fully meet the wishes of customers (parents). To implement this method, one should specify the requirements of the consumer. After that, by translating the requirements of consumers into general characteristics (quality indicators), comparing consumer and technical characteristics with each other, one can find cases of both independence and positive and negative correlation. After filling out the table and plotting the chart, one can clearly see that the QFD method makes it possible to identify significant characteristics of education for the consumer. It is important to pay attention to the weak points and take measures to raise and improve them. Applying not only the methods discussed above, one can improve the quality of education at universities. This is the priority objective of society, gradually solving which we will be able to achieve more goals than each of us has now.

\section{References}

Bonkalo, T.I., Erofeeva, M.A. \& Gorokhova, I.V. (2008). The main categories and concepts of special pedagogy and psychology. Kolomna: KSPI.

Bragin, Yu.V. \& Korolkov, V.F. (2013). Way QFD: design and production of products based on consumer expectations. Yaroslavl: Quality Center.

Decree of the President of the Russian Federation. (2018). Decree of 05/07/2018, N. 204 "On the national goals and strategic objectives of the development of the Russian Federation for the period until 2024". URL: http://kremlin.ru/acts/bank/43027

Efimov, V.V. (2007). Improving the quality of products, processes and resources. Moscow: Knorus.

Gludkin, O.P., Gorbunov, N.M. \& Zorin, Yu.V. (2011). Universal quality management. Moscow: Hotline - Telecom.

Goloshumova G.S., Gribkova O.V., Kidinov A.V., Tkhugo M.M., Chernova O.E., Telysheva N.N., Agadzhanova E.R. (2019b). Specific features of life orientations among students 
and their interrelation with professional formation. Revista Praxis Educacional, 15(34), 673-682.

Goloshumova, G.S., Ershova, O.V., Salakhova, V.B., Kidinov, A.V., Nalichaeva, S.A., Yanysheva, V.A. (2019a). Information and educational environment of higher school as a factor of the formation of coping strategies in the structure of students' personality (ecological and psychological aspect). EurAsian Journal of BioSciences, 13(2), 18671874.

Ishkov, A.D. (2014). The features of self-organization of adults studying at technical university. Procedia - Social and Behavioral Sciences, 142, 54-58.

Ishkov, A.D. \& Magera, T.N. (2015). Emotional competency in an engineering university: yes or no? Procedia Engineering, 117, 148-153.

Kostin, V.A. (2015) Instrumental determination of social efficiency of innovative projects implemented by enterprises defense industrial complex. Laws and Trends of Science Development: collection of articles of the International scientific-practical conference. Ufa: Aeterna, pp. 102-103.

Kroeger, O. \& Tewson J. (2011). Types of people. Moscow: Perseus, Veche, ACT.

Kuzmin, A.M. (2012). The history of the emergence, development and use of the method of deployment of the quality function. Methods of quality management, 1(2), 97-112.

Leontev, M.G. (2016). Innovative Approaches in Distance Education in the Field of Environmental Management and Environmental Technologies. MATEC Web of Conferences, 73, 07005. DOI: http://dx.doi.org/10.1051/matecconf/2016730700

Leontev, M.G. (2017). Impact of organizational culture, satisfaction of employees and students on the quality of education in University of Civil Engineering. MATEC Web of Conferences, 106, 09005. DOI: https://doi.org/10.1051/matecconf/20171060900

Leontev, M.G., Bondarenko, N.G., Shebzuhova, T.A., Butko, S.S. \& Egorova, L.I. (2018). Improving the efficiency of university management: Teacher's performance monitoring as a tool to promote the quality of education. European Research Studies Journal, 21(2), 527-540.

Miloradova, N.G. \& Ishkov, A.D. (2019a) Development of the technique of the universal social-and-psychological competences formation. International Journal of Applied Exercise Physiology, 8(2), 994-1002.

Miloradova, N.G. \& Ishkov, A.D. (2019b). Training of the highly qualified personnel in the postgraduate study in Russia and Tajikistan: results of the sociological poll. International Journal of Applied Exercise Physiology, 8(3), 373-380.

Mitin S.N., Kidinov A.V., Fedotov S.N., Leontev M.G., Bolotova A.K., Kalinin I.V. (2018). Modern models of career readiness. Modern Journal of Language Teaching Methods, 8(3), 78-86.

Popov, S.A. Surkova, T.V. \& Babkin, P.Yu. (2013). QFD: method for increasing product competitiveness. Bulletin of the International Academy of System Researches. Informatics, Ecology, Economy, 15(2), 134-138.

Pryadko, I. \& Ishkov, A. (2016). The problem of using logic in structural mechanics and electrical engineering as viewed by the Russian researcher Boris Biryukov. Procedia Engineering, 165, 1162-1167.

Samodurova, M.V. (2011). Economic and organizational tools to improve the quality of the Russian higher education system: PhD Thesis. Moscow: Moscow Psychological and Social Institute. 